\title{
SOURCES OF VALUE-ADDED IN V4 AUTOMOTIVE GVCS: THE CASE OF TRANSPORT AND STORAGE SERVICES AND FIRM-LEVEL TECHNOLOGY ABSORPTION
}

\author{
Minárik, M., Zábojník, S., Pásztorová, J.
}

Marek Minárik / University of Economics in Bratislava, Faculty of Commerce, Department of International Trade, Dolnozemská cesta 1, Bratislava, Slovakia. Email: marek.minarik@euba.sk

Stanislav Zábojník / University of Economics in Bratislava, Faculty of Commerce, Department of International Trade, Dolnozemská cesta 1, Bratislava, Slovakia.Email: stanislav.zabojnik@euba.sk Janka Pásztorová / University of Economics in Bratislava, Faculty of Commerce, Department of International Trade, Dolnozemská cesta 1, Bratislava, Slovakia.Email: janka.pasztorova@euba.sk

\begin{abstract}
Within V4 automotive Global Value Chains (GVCs), technologies absorbed by the corporate sector represent a significant impact on the level of value-added created within the economy. Sectoral and geographic targeting of our research is determined by the export of motor vehicles, trailers, and semi-trailers produced in the V4 countries. The article's main objective was to investigate the role of services provided by V4 countries within GVCs with an emphasis on transport and storage. The authors used the method of linear regression analysis to answer two central research questions. Is there a synergic or spillover effect within the automotive clusters of the V4 countries in creating value-added originating in the logistic services? What role absorption of technology at the firm level in EU27 countries (the most important trading partners of the V4 countries) plays in creating value-added in the V4 automotive sector? Authors found differentiated results within V4 countries, confirming the hypothesis related to technology absorption.

Implications for Central European audience: Despite high V4 export performance, the research suggests how to increase the value-added through higher involvement within GVCs (particularly the automotive industry). The paper demonstrates a positive impact of importing transport services from the EU countries to some V4 countries (Slovakia, Czechia, and Poland) and its value-added content in gross exports. For any V4 country, an increase in the quality of the business environment of EU trade partners (measured as the corporate level of technology absorption) results in a lower value-added creation, quite significantly, with lower effect in the case of Czechia, but more than 15\% decrease in case of Poland, Hungary, and Slovakia.
\end{abstract}

Keywords: value-added; automotive industry; Global Value Chains; transport and storage JEL Classification codes: F13, F42 


\section{Introduction}

The conventional approach to international trade is that each country produces goods and provides commercial services exported as final products to consumers abroad. However, in today's international business, described type of trade only represents around $30 \%$ of general merchandise and commercial services international trade. In reality, about $70 \%$ of international trade today involves global value chains, as services, raw materials, parts, and components cross borders - often numerous times (OECD, 2019; Zábojník et al., 2020). The phenomenon of how many intermediate products a country imports in order to produce a product and of how many products a country exports to another country in order to create new products draws the attention to value-added trade research (Folfas \& Udvari, 2019) and the problematics of global value chains (GVCs). GVCs as a special issue of international trade theory started to be a topic of economic research after the 'New Trade Theory' which indicates how product completion is fragmented in countries, regions, and continents, and where companies outsourcing and offshoring product assembly activities subsequently benefit from comparative advantages in countries where they relocated such activity.

GVCs depend on the fragmentation of production and trade in intermediate goods to take advantage of the cost advantages of each site or stage in the chain up to the level of assembly. GVCs are typically used by multinational companies and are becoming more critical (OECD, 2015), despite the disturbances in international markets brought about by the global pandemic COVID-19.

Especially after the late ' 90 s, the governments of V4 countries started to focus their national economies on inflows of foreign direct investment via systematic improvement of the investment climate. Large multinational companies that established their affiliates in the region began to use a favourable ratio of productivity (especially of the labour force) and labour costs, and in many V4 regions, major Western European and Asian producers began to emerge. The industrial nature of these countries also drove export performance. This effect of export growth increased even more after 2004 - the accession of these countries to the EU. However, a problematic aspect began to be the character of domestic economies. The countries (V4) had exceptional export performance (measured as the share of gross exports on GDP, especially the Slovak Republic, Czechia, and Hungary) but were dominated by assembly centres, not covering the complex activities within the GVC by domestic subcontractors. Already the first outputs within the TiVA methodology indicated that high value-added activities had mainly remained in the headquarters of MNEs within the home countries. A very specific sector where this trend is still dominant in the automotive industry. According to OECD data (2021), domestic value-added in the gross exports of the automotive industry in the Slovak Republic covers only $40.1 \%$, in the case of Hungary only $39.6 \%$, and in the Czech Republic 49.5\%. Therefore, researchers and policymakers raised the legitimate question of how value-added in gross exports can be increased to maximise export performance effect on domestic GDP growth. One of the recommendations is to increase the presence of the commercial services sector and their share in gross exports (primarily the automotive industry), as due to the nature of commercial services - the decisive value-added is realised in the domestic economy. This paper deals with the role and importance of the commercial services sector provided by the V4 countries within the GVCs. It emphasises transport and storage as a critical element in their pilot export sector - the automotive industry. 


\section{Theoretical background and literature review}

The value could either be contained within one single firm as a whole or divided among many different firms (Calabrese, 2018). It can be contained within one single geographical location or spread over the international environment globe. Value-added describes the difference between the price of a product offered by a company to its customers and the production cost spent by the company (Porter, 1985). The sudden rise in the import contents of exports, especially for the intermediary goods, became the main reason for the development of the value chain issue. In comparison, the import content of export describes the number of imported materials that will also contribute to the exports of a country. According to P. Lamy (2012), the ratio for import contents of exports in 1990 was around $20 \%$, which rose in 2010 up to $40 \%$, and $70 \%$, especially in Asia. Aside from these, there are some predictions of this ratio to be raised up to $60 \%$ import contents of global exports for 2030 .

The Global Value Chain (GVC) concept consists of two main dimensions: the global and local dimensions. The global dimension comes out of the input-output structure (Figure 1), the geographic scope, and the governance structure (Gereffi, 1994). The local dimension comes from the local institution's industry stakeholders, upgrading product, process, function, and chain (Calabrese, 2018).

The term Global Value Chain is derived from Porter's (1985) term Value Chain. The basis for all of these terms is represented by the value and value-added activities of an organisation or a firm participating in international business operations, primarily via import and export operations or offshoring activities from several countries. The first concept of a global commodity chain was introduced by Gereffi (1994) while explaining the example of the clothing industry. This concept consisted of a detailed description of the supply chain and operations from the raw material to the production of the final product. Nevertheless, the term 'global commodity chain' began to be used in the 1980s, when world trade and value chains became the central focus of the literature and research (Porter, 1985). Terms such as 'commodity chain' and 'value chain' are very similar, but 'value chain' is more complex such that it tends to describe the organisation of production (Bair, 2005; Zábojník et al., 2020).

GVC is closely related to information and communication technologies (ICT). Their central role can be defined in three fundamental concepts (Calabrese, 2018):

- Coordination of complexity at distance

- Reduction of the costs of specialisation and fostering of functional unbundling

- Reduction of the benefits of specialisation and disfavoring of functional unbundling. 
Figure 1 | Input-Output structure: A top-down definition of the automotive industry based on NACE classification

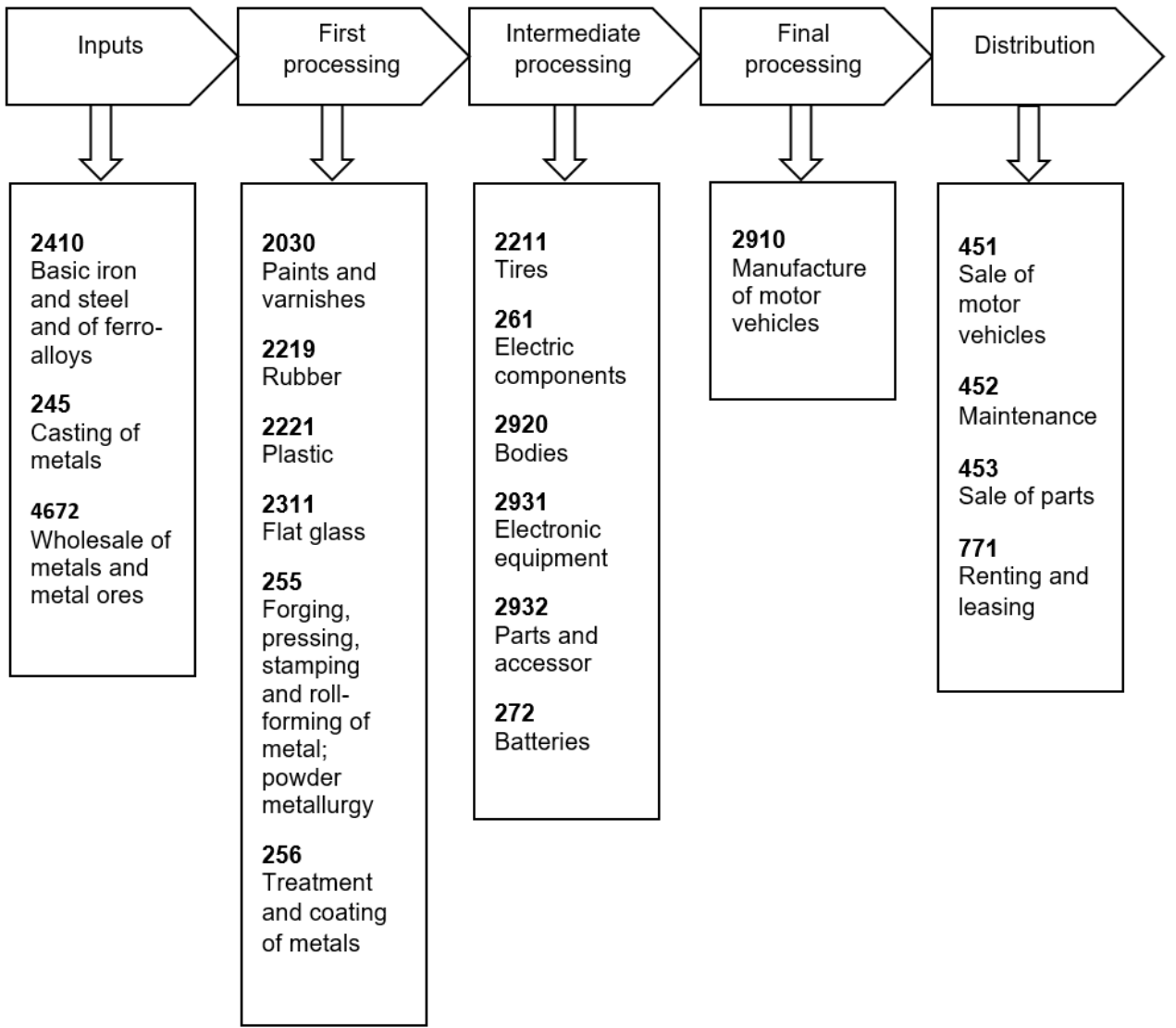

Research \& Development: 7112 Engineering activities; 7120 Technical testing; 741 Specialised design activities

Machinery: $\mathbf{2 8 1}$ general purpose machinery; $\mathbf{2 8 4}$ Machine tools; 289 Other machinery

Source: authors' own elaboration based on Calabrese (2018) and NACE classification

The third concept is often identified as a negative impact of both the digitalisation on the GVC and the firm level of technology absorption on the value-added creation, mainly within the developing countries.

GVC is also closely related to the economy of geography and the significance of a countries' location in geographical space (Krugman et al., 1991). Basics of this economic theory comprise:

- Centralisation of production at the market with significant demand and subsequent export to other markets at a certain level of transport costs. 
- $\quad$ Strong demand attracts new firms, and they attract new workers, and the new workers create the effect of the size of the domestic market - the source of agglomeration creation.

- $\quad$ The concept of core and periphery of economic activity is due to the arrival of new firms. The core represents modern firms, and the periphery represents traditional firms.

Forces of agglomeration enhance the attraction to clusters, and the clusters enhance the knowledge spillovers in favour of co-location with customers and intermediate goods supplies.

The concept of GVC is innovating into the concept of global value 'network' starting at the period around 2007-2008 (global financial and economic crisis). The principal reason was that the interconnection and collaboration between businesses around the globe began to increase (Calabrese, 2018). Each country specialises in those parts of the production process in which they have a specific comparative advantage. State-of-the-art theories in international business come with the transformation of GVCs into a 'global value network' (OECD, 2013). At the same time, the network represents the complexity of the interactions among global producers such that the 'economic processes must be conceptualised in terms of a complex circuitry with a multiplicity of linkages and feedback loops rather than just "simple" circuits or, even worse, linear flows' (Hudson, 2004, p.18).

More studies investigated value-added, and its importance within international trade flows, and it is because value-added demonstrated a close association with GDP creation. Therefore, more authors researched possible sources of higher value-added in exports. Several scholars, in their research, aimed to target feasible changes within GVCs that could contribute to higher value-added activities needed for governments (Humphrey \& Schmitz, 2002; Fernandez-Stark et al., 2014). While on the other hand, several studies typically associated with V4 countries (e.g., Dębkowska et al., 2019; Folfas, 2017; Luptáčik et al., 2013) focused on the automotive industry since the lower value-added in automotive exports is primarily a problem in the V4 countries (mainly Hungary, Slovakia, and Czechia).

Global value chains or networks are identified within every industry, but the following research focused on the automotive sector because of its specific role within the V4 export structure and relatively low value-added exports (Zábojník et al., 2020). The automotive GVC is represented by a highly concentrated structure of the firms, including fewer big companies such as car manufacturers and global suppliers. The whole structure of the GVC is comprised of a pyramid shape, where the big companies tend to exercise an extraordinary amount of power over the smaller firms, which are located at lower levels of the pyramid (Figure 2). 


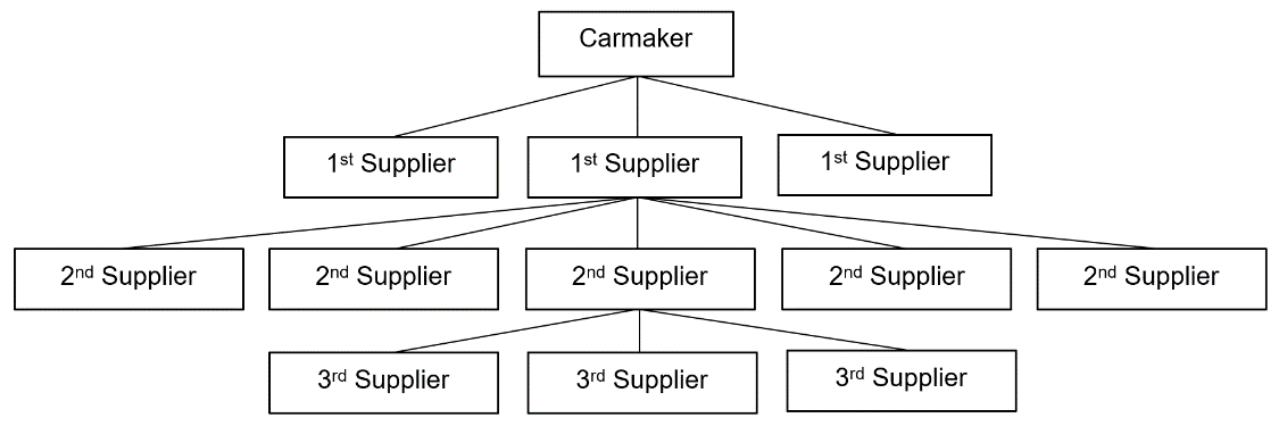

Source: Calabrese (2018)

The integration processes in the automotive industry have been developing since the mid1980s. Within this same era, the final vehicle assembly and parts production has been located to the markets of robust demand. In the case of Visegrad group countries (V4), the final consumption markets could be identified mainly with EU 27 countries.

The automotive industry has characteristic features such as few fully generic parts or subsystems that can be used in a wide variety of final products without extensive customisation (Calabrese, 2018). This idea is consistent with the push strategy within logistics.

The changes like the production techniques involve implementing IT and computing services, which are subsequently reflected in offshoring and outsourcing of the manufacturing process (Baldwin et al., 2015; Grossman \& Rossi-Hansberg, 2008). This eventually resulted in the automation of production. The COVID-19 economic effects even accelerated the integration of such technologies. Therefore, companies could increase the usage of services such as IT, telecommunication, and transportation, to bridge geographically dispersed production points and to overcome space and time issues for trade (Börjesson \& Eliasson, 2019).

V4 countries are particularly addressed with the issue of lower value-added in gross export, primarily within automotive and supplying sectors. The article focuses on transportation and storage services because they are one of three prominent service sectors which contribute to export value more with retail and wholesale. The distanced locations of the manufacturing firms around the globe and their ever-increasing numbers have eventually increased the importance of the transportation sector. With the increased manufacturing units of a single firm, the goods need to be transported among these units before finally reaching the consumers. However, shipping among these geographically dispersed production units in the meantime has been a challenge for the companies, which is resolved by the transportation sector. A logical question can be raised within our research topic if the high domestic valueadded in exports should be an objective for policymakers.

Our research is based on two key concepts: servicification (Baldwin et al., 2015) and the smile curve. They both refer to the impact of increasing commercial services, which is considered a key source of value-added in manufacturing the final goods. This was also one of the reasons for the development of the 'value-added trade' principle (Koopman et al., 2014; Timmer et al., 2014) and sizeable input-output database such as the World Input-Output Database (WIOD) and Trade in Value Added (TiVA) on the multinational principles. The term 
'servicification' is associated with the services used during the completion and exportation of manufactured goods. These services primarily comprise research and development, transportation, business services, retail and wholesale services, etc. The increasing importance of services in value-added creation demonstrates that the content of service value-added of all exports has significantly increased while the value-added from manufacturing had fallen over the last decades (Baldwin et al., 2015). In other words, the services are more critical, and manufacturing is a less critical source in export value creation. The claim is valid for all the countries participating in the international division of labour.

\section{Figure 3 | The Smile Curve of GVCs}

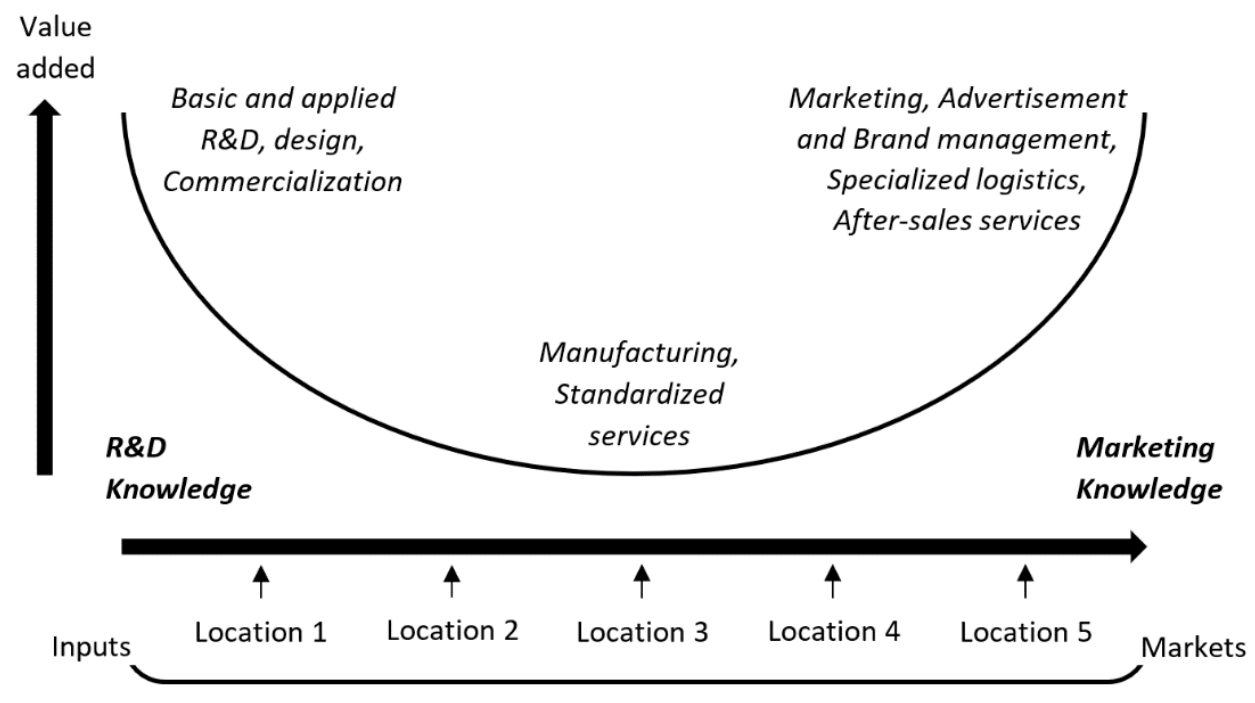

\section{VALUE CHAIN DISAGGREGATION}

Source: processed by Zábojník et al. (2020) according to initial work of Shih (1992)

The smile curve (Figure 3) identifies the production process accompanied by the low valueadded creation within more activities and many developing countries, whereas the V4 countries also face this issue. Countries have endless opportunities to participate in the value chain (Biesebroeck \& Sturgeon, 2011). Increased participation in GVC leads to higher domestic value-added (Faezeh et al., 2019), but the effect is significant only for middle- and high-income countries (Cattaneo et al., 2010). The key determinants of their participation within GVC are their geographical focus, market size, development level, etc. (Kowalski et al., 2015).

In order to confront the initial idea of value-added creation and to support the research question, several studies are targeted. Such as, according to Dollar et al. (2019), a higher domestic value-added does not mean that total value-added is exported and hence more GDP, and it is because the imported goods and services are crucial support to a country's competitiveness.

Researching a position of the value-added within gross exports is an important principle, especially within the V4 countries and their structure of automotive exports. Several researchers claimed that added value creation was more successfully triggered in some 
countries (Czechia), whereas some countries lacked a highly qualified labour force. Due to this, it will be challenging for such countries to transform the GVCs and the position of domestic companies within them, e.g. Slovakia (Pavlínek, 2018). Some authors recommend orientating more on commercial services' exports at the policy-making level, while others are researching the role of technology absorption. Lorentzen et al. (2010) targeted the usage of automotive GVCs in CEE countries proved that technology diffusion occurs within these countries. As a result, the host countries absorb more technology which is immediately apparent and commonly believed. This further confirms the conclusions of Goldberg et al. (2010), who proved that regions receiving FDI inflows in the business services sector facilitated increased productivity in the host economies, whereas the productivity was higher, especially in sectors using these services. This is particularly valid for the countries of V4 regions as dominant receivers of automotive FDI inflows since the 1990s. Some of the most recent works identify the automotive exports of V4 countries as a framework for the coreperiphery relationship apparent in these production processes (Gerocs \& Pinkasz, 2019). Another study investigating the impact of the COVID-19 crisis on the automotive sector of V4 countries reveals that CEE automotive sector could have a fragile future. Subsequently, value-added in the automotive sector will be the decisive factor for the subsequent economic development of the V4 region. Therefore, business services and firm-level technology absorption (as proposed by Lorentzen et al., 2010) can be the vital sources of value-added creation of the V4 automotive exports, and the research investigates its impact on valueadded creation.

\section{Methodology}

This article evaluates the role of commercial services in GVCs, while emphasising transport and storage services. Our research will also be highlighting the issue encountered by the corporate sector while integrating new technologies., which could also be identified through the Global Competitiveness Index (GCI) indicator, Firm-level technology absorption. The sector analysis will focus on the research of the automotive sector represented by exports of motor vehicles, trailers, and semi-trailers. The geographical focus of the research will be represented by all V4 countries - Slovakia (SK), Czech Republic (CZ), Poland (PL), and Hungary $(\mathrm{HU})$, where the automotive sector plays an important role. For the purpose of this research, a unique database was created, which is based on the OECD data. These data form part of the Trade in Value Added (TiVA) database, which offers the possibility to select exporting country with exporting industry and source country with source industry. With the help of this database, it could be clearly identified where the value-added is created. We selected motor vehicles, trailers, and semi-trailers for each V4 country - SK, CZ, PL, and HUwhich are exporting countries for our research. The transport and storage services, where the value-added was detected to be created, were selected for the observed countries.

In comparison, all source countries belong to EU27 (already excluding the United Kingdom). The resulting values show the level of value-added (in millions of USD) originated in transport and storage, representing the export of motor vehicles, trailers, and semi-trailers for 2015 (the latest data available). This indicator is derived from the latest version of OECD's Inter-Country Input-Output database and provides estimates of gross exports of goods and services by exporting industry $\mathrm{i}$ in country $\mathrm{c}$, broken down by the value-added originating from source industry j in source country s (OECD, 2021). 
The OECD also provides data, which form part of the trade-in services database by partner economy. This database was used to select the indicator - the total import of transport services (in millions of USD) from each EU27 country to each of the V4 countries for 2015.

To complete all the indicators necessary for our research, we included the $\mathrm{GCl}$ indicator Firm level of technology absorption in EU27 countries for 2012-2013 by the World Economic Forum (WEF). The parameter describes the quality of the business environment related to the corporate level of technology.

\subsection{Models}

The data of indicators mentioned above were used for the creation of simple regression models: regression model A for SK as a country exporting motor vehicles, trailers, and semitrailers; regression model $\mathrm{B}$ for $\mathrm{CZ}$ as a country exporting motor vehicles, trailers, and semitrailers; regression model $\mathrm{C}$ for $\mathrm{PL}$ as a country exporting motor vehicles, trailers and semitrailers; and regression model $\mathrm{D}$ for $\mathrm{HU}$ as a country exporting motor vehicles, trailers and semi-trailers. These models have a similar basis - the dependent variable is expressed as the level of value-added originated in transport and storage in the export of motor vehicles, trailers, and semi-trailers in 2015 - for each of the V4 countries.

The independent variables can vary among these models due to some differences among the V4 countries, but the main idea of this research is to confirm some similarities among the V4 countries; some of the dependent variables will be identified in all the models. These models will help to either confirm or to reject the hypothesis for all V4 countries:

H1: The value-added incorporated within transport and storage within exports of the automotive industry of each V4 country depends on the total import of transport services from the EU 27 countries.

This hypothesis was supplemented with one research question:

RQ1: Is there a synergic or spillover effect within the automotive clusters of the V4 countries in creating value-added originating in the logistic services?

H2: The amount of value-added originated in transport and storage in exports of automotive industry of each V4 country depends on the quality of the business environment of the EU27 countries - the main V4 trade partners - defined through the corporate level of technology absorption.

This hypothesis was supplemented with one research question, too:

RQ2: What role does the firm level of technology absorption in EU27 countries (the most important trading partners of the V4 countries) play in creating value-added in the V4 automotive sector?

The dependent variable for this research will comprise the value-added in transport and storage in the export of motor vehicles, trailers, and semi-trailers. The creation of any regression model requires implementing at least one-year time lag among the events where the independent variables affected the dependent one. While on the other hand, the firm level of technology absorption is expressed as the independent variable for this research. If the most recent available data for the dependent variable is taken from the years 2015, the data for the dependent variable will be targeted from 2012-2013. This highlights a two-year lag 
among the effects of the independent variable on the dependent one. We expect the twoyear time lag between the moment when this indicator changes and the moment when the change will impact the level of value-added creation. The data for the dependent variable (the total import of transport services in millions of USD from the EU27 countries to each of the V4 countries) are from 2015. We have intentionally implemented the data for this variable from 2015 (without any time lag) because we suppose that there is a relation between the amount of total import of transport services in 2015 to each V4 country and the level of valueadded of the same countries in exports of motor vehicles, trailers and semi-trailers, which originates in transport and storage services from the EU 27 countries without any time lag in the same year 2015 .

To form the regression models, we used the OLS and the heteroskedasticity corrected estimators in the Gretl statistical program. Due to the heteroskedasticity in model A for SK, B for CZ, and C for PL, the OLS estimator was changed to the more suitable Heteroskedasticity corrected estimator, which means that the condition of homoskedasticity of linear expression was also met. Our research was completed with all the necessary statistical data (mean, median, minimum, maximum, std. dev., CV, Skewness, Ex. Kurtosis, 5\% Perc., 95\% perc., IQR range, and missing obs.).

\section{Results}

The model creation is described in the text below. The authors created four separate models (for each of the V4 countries), starting with SK and CZ and finishing with PL and HU.

Table 1 | Model A, Slovakia: model Heteroskedasticity-corrected, using observations 1-27 ( $\mathrm{n}=$ 25), missing or incomplete observations dropped: 2 , dependent variable: I_VA_SK

\begin{tabular}{lccccc}
\hline & Coefficient & Std. Error & $t$-ratio & \multicolumn{2}{c}{$p$-value } \\
\hline I_IM_SK_TRANSPORT_Mil_USD & 0.315262 & 0.0806574 & 3.909 & $0.0008 \quad{ }^{* * *}$ \\
I_IM_CZ_TRANSPORT_Mil_USD & 0.901866 & 0.122624 & 7.355 & $<0.0001 \quad * * *$ \\
I_Firm_level_technology_absorption & -1.79829 & 0.214191 & -8.396 & $<0.0001 \quad * * *$ \\
Sum squared resid & 70.06422 SE of regression & 1.784583 \\
Uncentered R-squared & 0.912057 Centered R-squared & 0.943050 \\
F(3, 22) & 76.05362 P-value(F) & $9.03 e-12$ \\
Log-likelihood & -48.35517 Akaike criterion & 102.7103 \\
Schwarz criterion & 106.3670 Hannan-Quinn & 103.7245 \\
Mean dependent var & 0.983057 S.D. dependent var & 1.752089 \\
Sum squared resid & 9.330366 SE of regression & 0.651235
\end{tabular}

Source: authors' own elaboration based on the data of the OECD (2015) - TIVA database 2015, WEF (2012) - GCl 2012-2013

The linear regression model A (Table.1) was also tested for normality of residual - Null hypothesis: error is normally distributed. Test statistic: Chi-square $(2)=3.52297$, with $p$ value $=0.17179$ 
The linear regression model $A$ has the following form:

$$
\hat{y}_{i}=0.315262 x_{i 1}+0.901866 x_{i 2}-1.79829 x_{i 3}
$$

- $\quad X_{i 1}$ is the volume of imported transport services from the EU26 countries to SK (import from SK to SK is excluded) (OECD, 2015),

- $\quad \mathrm{X}_{\mathrm{i} 2}$ is the volume of imported transport services from the EU26 countries to $\mathrm{CZ}$ (import from CZ to CZ is excluded) (OECD, 2015),

- $\mathrm{x}_{3}$ is the quality of business environment defined as firm-level of technology absorption in EU27 countries (GCl 2012-2013),

- $\quad \hat{y}_{i}$ is the level of value-added in the export of motor vehicles, trailers, and semitrailers originated in transport and storage in SK.

The linear regression model A claims: if the volume of imported transport services from the EU26 countries to SK is increased by $10 \%$, it would also increase the level of value-added in the export of motor vehicles, trailers, and semi-trailers originated in transport and storage in SK would increase by $3.15 \%$. However, the condition applies those certain factors remain unchanged such as the volume of imported transport services from the EU26 countries to CZ and the quality of business environment defined by firm-level technology absorption in EU27 countries. The claim is valid for the analysed countries.

On the other hand, if the volume of imported transport services from the EU26 countries to CZ is increased by $10 \%$, it could increase the level of value-added in the export of motor vehicles, trailers, and semi-trailers originated in transport and storage in SK will increase by $9.02 \%$. However, the conditions must apply such that the volume of imported transport services from the EU26 countries to SK and the quality of business environment defined as firm-level of technology absorption in EU27 countries must remain unchanged. The claim is valid for the analysed countries. Both claims are from the situation in 2015.

If the quality of business environment defined as firm-level of technology absorption in EU27 countries is increased by $10 \%$ (the situation from 2012-2013), the level of value-added in the export of motor vehicles, trailers, and semi-trailers originated in transport and storage in SK would decrease by $17.98 \%$. However, the conditions will be applied such that the volume of imported transport services from EU26 countries to SK and the volume of imported transport services from EU26 countries to CZ will remain unchanged. The claim is valid for the analysed countries.

\subsection{Testing hypothesis for the variables}

The relevance of the research is based on testing the hypothesis for the variables from the regression model $A$, which was created in the previous part, starting with the volume of imported transport services from the EU26 countries to SK: H0: $\beta 1=0 ; H 1: \beta 1 \neq 0$; $|(0.315262-0) / 0.0806574|>2.074 ; 3.909>2.074$. This allows us to reject $\mathrm{H}_{0}$ and claim that the coefficient for the volume of imported transport services from the EU26 countries to SK is statistically significant - this variable affects the level of value-added in the export of motor vehicles, trailers and semi-trailers originated in transport and storage in SK. We did the same testing for the rest of the variables, and we claim that all of them within this model is statistically significant. 


\subsection{Statistical significance verification of the regression model A}

After a statistical significance verification of model $A$ at the level of significance $\alpha=0.1: \mathrm{H}_{0}$ : model $A$ is not statistically significant, $\mathrm{H}_{1}$ : model $A$ is statistically significant. The critical value of $F_{0,1}(3.22)=3.04912$, the calculated $F$ value of the statistics from our model is 76.05362 . Since $76.05362>3.04912$, we reject the null hypothesis $\mathrm{H}_{0}$. The $\mathrm{p}$-value in our regression analysis allows us to reject the null hypothesis. The coefficient of determination reaches the value $\mathrm{R}^{2}=0.912057$. It means that the proposed regression model with independent variables $\mathrm{x}_{\mathrm{i} 1}$ (the volume of imported transport services from the EU26 countries to SK), $\mathrm{x}_{\mathrm{i} 2}$ (the volume of imported transport services from the EU26 countries to CZ)- and $x_{i 3}$ (firm-level of technology absorption in EU27 countries) can explain $91.21 \%$ of the variability of dependent variable $\hat{y}_{i}$ (the level of value-added in the export of motor vehicles, trailers and semi-trailers originated in transport and storage in SK). The remaining $8.79 \%$ of the variability of the dependent variable is caused by factors that are not included in this regression model and are represented by random effects.

The model of dependence of the level of value-added in the export of motor vehicles, trailers, and semi-trailers originated in transport and storage in Slovakia on the volume of imported transport services from the EU26 countries to SK, the volume of imported transport services from the EU26 countries to CZ and firm-level of technology absorption in EU27 countries is statistically significant.

The next part of our research was completed by the models for the remaining V4 countries, starting with $\mathrm{CZ}$ and $\mathrm{PL}$ and finishing with $\mathrm{HU}$.

Table 2 | Model B, Czech Republic: Heteroskedasticity-corrected, using observations 1-27 (n = 25), missing or incomplete observations dropped: 2, dependent variable: I_VA_CZ

\begin{tabular}{|c|c|c|c|c|c|}
\hline & Coefficient & Std. Error & t-ratio & $p$-value & \\
\hline $\begin{array}{l}\text { I_IM_CZ_TRANSPORT_Mil_U } \\
\text { SD }\end{array}$ & 0.993566 & 0.0949206 & 10.47 & $<0.0001$ & $* * *$ \\
\hline $\begin{array}{l}\text { IM_SK_TRANSPORT_Mil_US } \\
\text { D }\end{array}$ & 0.00327549 & 0.000983100 & 3.332 & 0.0030 & *** \\
\hline $\begin{array}{l}\text { I_Firm_level_technology_absor } \\
\text { ption }\end{array}$ & -1.28676 & 0.183746 & -7.003 & $<0.0001$ & *** \\
\hline Sum squared resid & \multicolumn{3}{|c|}{$50.68848 \mathrm{SE}$ of regression } & \multicolumn{2}{|c|}{1.517901} \\
\hline Uncentered R-squared & \multicolumn{3}{|c|}{0.927347 Centered R-squared } & \multicolumn{2}{|c|}{0.966839} \\
\hline$F(3,22)$ & \multicolumn{3}{|c|}{ 93.60371 P-value(F) } & \multicolumn{2}{|c|}{$1.11 \mathrm{e}-12$} \\
\hline Log-likelihood & \multicolumn{3}{|c|}{-44.30875 Akaike criterion } & \multicolumn{2}{|c|}{94.61750} \\
\hline Schwarz criterion & \multicolumn{3}{|c|}{ 98.27413 Hannan-Quinn } & \multicolumn{2}{|c|}{95.63169} \\
\hline
\end{tabular}

Source: authors' own elaboration based on the data of the OECD (2015) - TIVA database 2015, WEF (2012) - GCl 2012-2013

The model was also tested for normality of residual - Null hypothesis: error is normally distributed. Test statistic: Chi-square $(2)=4,11711$, with $p$-value $=0,127638$

The linear regression model has the following form: 
- $\mathrm{X}_{\mathrm{i} 1}$ is the volume of imported transport services from the EU26 countries to $\mathrm{CZ}$ (import from CZ to CZ is excluded) (OECD, 2015),

- $\mathrm{x}_{\mathrm{i} 2}$ is the volume of imported transport services from the EU26 countries to SK (import from SK to SK is excluded) (OECD, 2015),

- $\mathrm{x}_{\mathrm{i} 3}$ is the quality of business environment defined as firm-level of technology absorption in EU27 countries (GCl 2012-2013),

- $\quad \hat{y}_{i}$ is the level of value-added in the export of motor vehicles, trailers, and semitrailers originated in transport and storage in $\mathrm{CZ}$.

The linear regression model B (Table 2) claims: if the volume of imported transport services from the EU26 countries to CZ is increased by $10 \%$ (the situation from 2015), the level of value-added in the export of motor vehicles, trailers, and semi-trailers originated in transport and storage in $\mathrm{CZ}$ would increase by $9.94 \%$. However, the conditions must be applied such that the volume of imported transport services from the EU26 countries to SK and the quality of business environment expressed as firm-level of technology absorption in EU27 countries remain unchanged. The claim is valid for the analysed countries.

If the volume of imported transport services from the EU26 countries to SK is increased by 10 million USD (the situation from 2015), the level of value-added in the export of motor vehicles, trailers, and semi-trailers originating in transport and storage in $\mathrm{CZ}$ will increase by $0.03 \%$. However, the condition must apply such that the volume of imported transport services from the EU26 countries to $\mathrm{CZ}$ and the quality of business environment defined as firm-level of technology absorption in EU27 countries remain unchanged. The claim is valid for the analysed countries.

If the quality of business environment defined as firm-level of technology absorption in EU27 countries is increased by $10 \%$ (the situation from 2012-2013), the level of value-added in the export of motor vehicles, trailers, and semi-trailers originated in transport and storage in $\mathrm{CZ}$ would decrease by $12.87 \%$. However, the conditions must apply such that the volume of imported transport services from EU26 countries to $\mathrm{CZ}$ and the volume of imported transport services from EU26 countries to SK remain unchanged. The claim was valid for the analysed countries.

\subsection{Testing hypothesis for the variables}

The relevance of the research is based on testing the hypothesis for the variables from the regression model $B$ (Tab.2), which was created in the last part, starting with the volume of imported transport services from the EU26 countries to $C Z$ : $\mathrm{HO}: \beta 1=0 ; \mathrm{H} 1: \beta 1 \neq 0 ;(0.993566$ - 0) / $0.0949206 \mid>2.074 ; 10.47>2.074$. This allows us to reject $\mathrm{HO}$ and claim that the coefficient for the volume of imported transport services from the EU26 countries to CZ is statistically significant. This variable affects the value-added in the export of motor vehicles, trailers, and semi-trailers originating in transport and storage in $\mathrm{CZ}$. We did the same testing for the rest of the variables, and we claim that all of them within this model is statistically significant. 


\subsection{Statistical significance verification of the regression model B}

A statistical significance verification of the model $B$ at the level of significance $\alpha=0.10$ was done: $\mathrm{H}_{0}$ : model $\mathrm{B}$ is not statistically significant, $\mathrm{H}_{1}$ : model $\mathrm{B}$ is statistically significant. The critical value of $F_{0,1}(3.22)=3.04912$, the calculated $F$ value of the statistics from our model $B$ is 93.60371 . Since $93.60371>3.04912$, we reject the null hypothesis $\mathrm{H}_{0}$. The $\mathrm{p}$-value in our regression analysis allows us to reject the null hypothesis. The coefficient of determination reaches the value $\mathrm{R}^{2}=0.927347$. It means that the proposed regression model $B$ with independent variables $x_{i 1}$ (the volume of imported transport services from the EU26 countries to $\mathrm{CZ}$ ), $\mathrm{x}_{\mathrm{i} 2}$ (the volume of imported transport services from the EU26 countries to $\mathrm{SK}$ ) and $\mathrm{x}_{3}$ (firm-level of technology absorption in EU27 countries) is able to explain $92.73 \%$ of the variability of dependent variable $\hat{y}_{i}$ (the level of value-added in the export of motor vehicles, trailers and semi-trailers originated in transport and storage in $\mathrm{CZ}$ ). The remaining $7.27 \%$ of the variability of the dependent variable is caused by factors, which are not included in this regression model $\mathrm{B}$, and by random effects.

The model B of dependence of the level of value-added in the export of motor vehicles, trailers and semi-trailers originated in transport and storage in CZ on the volume of imported transport services from the EU26 countries to CZ, the volume of imported transport services from the EU26 countries to SK and firm-level of technology absorption in EU27 countries is statistically significant.

Table 3 | Model C, Poland: - model Heteroskedasticity-corrected, using observations 1-27 (n = 23), Missing or incomplete observations dropped: 4, Dependent variable: I_VA_PL

\begin{tabular}{lccccc}
\hline & Coefficient & Std. Error & t-ratio & \multicolumn{2}{c}{$p$-value } \\
\hline I_IM_PL_TRANSPORT_Mil_USD & 0.603667 & 0.0962797 & 6.270 & $<0.0001$ & $* * *$ \\
I_IM_SK_TRANSPORT_Mil_USD & 0.565017 & 0.117145 & 4.823 & 0.0001 & $* * *$ \\
I_IM_CZ_TRANSPORT_Mil_USD & 0.778443 & 0.104503 & 7.449 & $<0.0001{ }^{* * *}$ \\
I_IM_HU_TRANSPORT_Mil_USD & -0.882347 & 0.175836 & -5.018 & $<0.0001{ }^{* * *}$ \\
I_Firm_level_technology_absorption & -1.54636 & 0.205099 & -7.540 & $<0.0001{ }^{* * *}$ \\
Sum squared resid & 50.90962 SE of regression & & 1.681759 \\
Uncentered R-squared & 0.988058 Centered R-squared & & 0.989986 \\
F(5, 18) & 297.8473 P-value(F) & & $1.20 \mathrm{e}-16$ \\
Log-likelihood & -41.77300 Akaike criterion & & 93.54600 \\
Schwarz criterion & 99.22347 Hannan-Quinn & & 94.97387 \\
Mean dependent var & 0.808923 S.D. dependent var & & 1.605522 \\
Sum squared resid & 7.369544 SE of regression & & 0.639859
\end{tabular}

Source: authors' own elaboration based on the data of the OECD (2015) - TIVA database 2015, WEF (2012) - GCl 2012-2013

The linear regression model C (Table 3) was also tested for normality of residual - Null hypothesis: error is normally distributed. Test statistic: Chi-square $(2)=11.7128$, with $p$ value $=0.00286156$ 
The linear regression model has the following form:

$$
\hat{y}_{i}=0.603667 x_{i 1}+0.565017 x_{i 2}+0.778443 x_{i 3}-0.882347 x_{i 4}-1.54636 x_{i 5}
$$

- $\quad X_{i 1}$ is the volume of imported transport services from the EU26 countries to PL (import from PL to PL is excluded) (OECD, 2015),

- $\quad \mathrm{X}_{\mathrm{i} 2}$ is the volume of imported transport services from the EU26 countries to SK (import from SK to SK is excluded) (OECD, 2015),

- $\quad \mathrm{X}_{\mathrm{i}}$ is the volume of imported transport services from the EU26 countries to CZ (import from CZ to CZ is excluded) (OECD, 2015),

- $\quad \mathrm{X}_{\mathrm{i} 4}$ is the volume of imported transport services from the EU26 countries to HU (import from HU to HU is excluded) (OECD, 2015),

- $\quad \mathrm{X}_{55}$ is the quality of business environment defined as Firm level of technology absorption in EU27 countries (GCl 2012-2013),

- $\quad \hat{y}_{i}$ is the level of value-added in the export of motor vehicles, trailers, and semitrailers originated in transport and storage in PL.

The linear regression model $C$ claims: if the volume of imported transport services from the EU26 countries to PL is increased by $10 \%$ (the situation from 2015), the level of value-added in the export of motor vehicles, trailers, and semi-trailers originated in transport and storage in PL would increase by $6.04 \%$. However, some factors must remain unchanged such as the volume of imported transport services from the EU26 countries to SK, the volume of imported transport services from the EU26 countries to $\mathrm{CZ}$, the volume of imported transport services from the EU26 countries to $\mathrm{HU}$, and the quality of business environment defined with firmlevel of technology absorption in EU27 countries. The claim is valid for the analysed countries.

If the volume of imported transport services from the EU26 countries to SK is increased by $10 \%$ (the situation from 2015), the level of value-added in the export of motor vehicles, trailers and semi-trailers originated in transport and storage in PL would increase by $5.65 \%$. However, as a condition, certain factors must remain unchanged such as the volume of imported transport services from the EU26 countries to PL, the volume of imported transport services from the EU26 countries to $\mathrm{CZ}$, the volume of imported transport services from the EU26 countries to $\mathrm{HU}$ and the quality of business environment defined as firm-level of technology absorption in EU27 countries. The claim is valid for the analysed countries.

If the volume of imported transport services from the EU26 countries to CZ is increased by $10 \%$ (the situation from 2015), the level of value-added in the export of motor vehicles, trailers and semi-trailers originated in transport and storage in PL would increase by $7.78 \%$. However, certain factors must remain unchanged such as the volume of imported transport services from the EU26 countries to PL, the volume of imported transport services from the EU26 countries to SK, the volume of imported transport services from the EU26 countries to $\mathrm{HU}$, and the quality of business environment defined as firm-level of technology absorption in EU27 countries. The claim is valid for the analysed countries.

If the volume of imported transport services from the EU26 countries to $\mathrm{HU}$ is increased by $10 \%$ (the situation from 2015), the level of value-added in the export of motor vehicles, trailers and semi-trailers originated in transport and storage in PL would decrease by $8.82 \%$. However, certain factors must remain unchanged such as the volume of imported transport 
services from the EU26 countries to PL, the volume of imported transport services from the EU26 countries to SK, the volume of imported transport services from the EU26 countries to $\mathrm{CZ}$, and the quality of business environment defined as firm-level of technology absorption in EU27 countries. The claim is valid for the analysed countries.

If the quality of business environment defined as firm-level of technology absorption in EU27 countries is increased by $10 \%$ (the situation from 2012-2013), the level of value-added in the export of motor vehicles, trailers, and semi-trailers originated in transport and storage in PL would decrease by $15.46 \%$. However, conditions apply to require that certain factors must remain unchanged such as the volume of imported transport services from EU26 countries to PL, unchanged the volume of imported transport services from EU26 countries to SK, the volume of imported transport services from EU26 countries to $\mathrm{CZ}$, and the volume of imported transport services from EU26 countries to HU. The claim is valid for the analysed countries.

\subsection{Testing hypothesis for the variables}

The relevance of the research is based on testing the hypothesis for the variables from the regression model $\mathrm{C}$, which was created in the last part, starting with the volume of imported transport services from the EU26 countries to PL (import from PL to PL is excluded): H0: $\beta 1$ $=0 ; \mathrm{H} 1: \beta 1 \neq 0 ;|(0.603667-0) / 0.0962797|>2.101 ; 6.270>2.101$.

This allows us to reject $\mathrm{HO}$ and claim that the coefficient for the volume of imported transport services from the EU26 countries to PL is statistically significant - this variable affects the level of value-added in the export of motor vehicles, trailers and semi-trailers originated in transport and storage in PL. We did the same testing for the rest of the variables, and we claim that all of them within this model is statistically significant.

\subsection{Statistical significance verification of the regression model C}

A statistical significance verification of the model $\mathrm{C}$ at the level of significance $\alpha=0.1$ was done: $\mathrm{HO}$ : model is not statistically significant, $\mathrm{H} 1$ : model is statistically significant. The critical value of $F 0,1(5.18)=2.77285$, the calculated $F$ value of the statistics from our model is 297.8473. Since $297.8473>2.77285$, we reject the null hypothesis H0. The p-value in our regression analysis allows us to reject the null hypothesis. The coefficient of determination reaches the value $\mathrm{R} 2=0.988058$. It means that the proposed regression model $\mathrm{C}$ with independent variables xi1 (the volume of imported transport services from the EU26 countries to PL), xi2 (the volume of imported transport services from the EU26 countries to SK), xi3 (the volume of imported transport services from the EU26 countries to $\mathrm{CZ}$ ), xi4 (the volume of imported transport services from the EU26 countries to HU) and xi5 (firm-level of technology absorption in EU27 countries) explains $98.81 \%$ of the variability of dependent variable yi (the level of value-added in the export of motor vehicles, trailers and semi-trailers originated in transport and storage in PL). The remaining $1.19 \%$ of the variability of the dependent variable is caused by factors, which are not included in this regression model $\mathrm{C}$, and by random effects.

The model $\mathrm{C}$ of dependence of the level of value-added in the export of motor vehicles, trailers, and semi-trailers originated in transport and storage in PL on the volume of imported transport services from the EU26 countries to PL, the volume of imported transport services from the EU26 countries to SK, the volume of imported transport services from the EU26 
countries to $\mathrm{CZ}$, the volume of imported transport services from the EU26 countries to HU and firm-level of technology absorption in EU27 countries is statistically significant.

Table 4 | Model D, Hungary: model OLS, using observations 1-27 $(n=25)$, missing or incomplete observations dropped: 2, dependent variable: I_VA_HU

\begin{tabular}{lccccc}
\hline & Coefficient & Std. Error & t-ratio & \multicolumn{2}{c}{$p$-value } \\
\hline I_IM_HU_TRANSPORT_Mil_USD & 0.469290 & 0.148709 & 3.156 & 0.0046 & ${ }^{* * *}$ \\
I_IM_CZ_TRANSPORT_Mil_USD & 0.679300 & 0.156289 & 4.346 & 0.0003 & $* * *$ \\
I_Firm_level_technology_absor & -1.70793 & 0.200622 & -8.513 & $<0.0001 \quad * * *$ \\
Mean dependent var & 1.379665 SD dependent var & & 1.762499 \\
Sum squared resid & 7.940262 SE of regression & 0.600767 \\
Uncentered R-squared & 0.934991 Centered R-squared & & 0.893496 \\
F(3, 22) & 105.4712 P-value(F) & & $3.29 \mathrm{e}-13$ \\
Log-likelihood & -21.13684 Akaike criterion & & 48.27369 \\
Schwarz criterion & 51.93031 Hannan-Quinn & & 49.28788
\end{tabular}

Source: authors' own elaboration based on the data of the OECD (2015) - TIVA database 2015, WEF (2012) - GCl 2012-2013

Model D (Table 4) was tested for normality of residual - Null hypothesis: error is normally distributed. Test statistic: Chi-square $(2)=2.88888$, with $p$-value $=0.235878$

The linear regression model has the following form:

$\hat{y}_{i}=0.46929 x_{i 1}+0.6793 x_{i 2}-1.70793 x_{i 3}$

- $\mathrm{X}_{\mathrm{i} 1}$ is the volume of imported transport services from the EU26 countries to HU (import from HU to HU is excluded) (OECD, 2015),

- $\quad \mathrm{X}_{\mathrm{i} 2}$ is the volume of imported transport services from the EU26 countries to $\mathrm{CZ}$ (import from CZ to CZ is excluded) (OECD, 2015),

- $\quad \mathrm{x}_{3}$ is the quality of business environment defined as Firm level of technology absorption in EU27 countries (GCl 2012-2013),

- $\quad \hat{y}_{i}$ is the level of value-added in the export of motor vehicles, trailers, and semitrailers originated in transport and storage in $\mathrm{HU}$.

The linear regression model $D$ claims: if the volume of imported transport services from the EU26 countries to HU is increased by $10 \%$ (the situation from 2015), the level of value-added in the export of motor vehicles, trailers, and semi-trailers originated in transport and storage in $\mathrm{HU}$ would increase by $4.69 \%$. However, the condition applies such that the volume of imported transport services from the EU26 countries to CZ and the quality of business environment defined with firm-level of technology absorption in EU27 countries remain unchanged. The claim is valid for the analysed countries.

If the volume of imported transport services from the EU26 countries to CZ is increased by $10 \%$ (the situation from 2015), the level of value-added in the export of motor vehicles, trailers, and semi-trailers originating in transport and storage in $\mathrm{HU}$ would increase by $6.79 \%$. However, the conditions must apply such that the volume of imported transport services from 
the EU26 countries to $\mathrm{HU}$ and the quality of business environment defined as firm-level of technology absorption in EU27 countries must remain unchanged. The claim is valid for the analysed countries.

If the quality of business environment defined as firm-level of technology absorption in EU27 countries is increased by $10 \%$ (the situation from 2012-2013), the level of value-added in the export of motor vehicles, trailers, and semi-trailers originated in transport and storage in $\mathrm{HU}$ would decrease by $17.08 \%$. However, the conditions must apply, such as the volume of imported transport services from EU26 countries to $\mathrm{HU}$ and the volume of imported transport services from EU26 countries to CZ. The claim valid for the analysed countries must remain unchanged.

\subsection{Testing hypothesis for the variables}

The relevance of the research is based on testing the hypothesis for the variables from the regression model $D$, which was created in the previous part, starting with the volume of imported transport services from the EU26 countries to $\mathrm{HU}: \mathrm{HO}: \beta 1=0 ; \mathrm{H} 1: \beta 1 \neq 0 ; \mid(0.46929$ $-0) / 0.148709 \mid>2.074 ; 3.156>2.074$. This allows us to reject $\mathrm{H}_{0}$ and claim that the coefficient for the volume of imported transport services from the EU26 countries to HU is statistically significant - this variable affects the level of value-added in the export of motor vehicles, trailers, and semi-trailers originated in transport and storage in $\mathrm{HU}$. We did the same testing for the rest of the variables, and we claim that all of them within this model is statistically significant.

\subsection{Statistical significance verification of the regression model D}

A statistical significance verification of the model $D$ at the level of significance $\alpha=0.1$ was done: $\mathrm{HO}$ : model $\mathrm{D}$ is not statistically significant, $\mathrm{H1}$ : model $\mathrm{D}$ is statistically significant. The critical value of $F 0,1(3.22)=3.04912$, the calculated $F$ value of the statistics from our model $\mathrm{D}$ is 105.4712 . Since $87.17057>3.04912$, we reject the null hypothesis $\mathrm{H} 0$. The $\mathrm{p}$-value in our regression analysis allows us to reject the null hypothesis. The coefficient of determination reaches the value $\mathrm{R} 2=0.934991$. It means that the proposed regression model D with independent variables xi1 (the volume of imported transport services from the EU26 countries to $\mathrm{HU}$ ), xi2 (the volume of imported transport services from the EU26 countries to $\mathrm{CZ}$ and xi3 (firm-level of technology absorption in EU27 countries) is able to explain $93.50 \%$ of the variability of dependent variable ŷi (the level of value-added in the export of motor vehicles, trailers and semi-trailers originated in transport and storage in $\mathrm{HU}$ ). The remaining $6.50 \%$ of the variability of the dependent variable is caused by factors, which are not included in this regression model $\mathrm{D}$, and by random effects.

The linear regression model was tested for the presence of heteroscedasticity, applying White's test - Null hypothesis: heteroskedasticity not present. Test statistic: $L M=2.7557$, with $\mathrm{p}$-value $=\mathrm{P}($ Chi-square $(9)>2.7557)=0.973198$, no heteroskedasticity is present in the model $D$ due to $p$-value $>0.05$.

The model $D$ of dependence of the level of value-added in the export of motor vehicles, trailers, and semi-trailers originated in transport and storage in $\mathrm{HU}$ on the volume of imported transport services from the EU26 countries to HU, the volume of imported transport services from the EU26 countries to CZ and firm-level of technology absorption in EU27 countries is statistically significant. 


\section{Discussion}

All four models ( $A, B, C$, and D) proved that in the case of the value-added creation within the exports of the automotive industry of any V4 country, a 1\% increase in the quality of the business environment in terms of the corporate level of technology absorption in the EU27 countries results in a decrease in the value added creation differently for different countries involved. In the case of CZ, a significant decrease down to $13 \%$, more than $15 \%$ in the case of $\mathrm{PL}$, more than $17 \%$ decrease in the case of $\mathrm{HU}$, and almost $18 \%$ decrease in the case of SK. This finding correlates with the result of (Ružeková et al., 2020) and confirms the particular importance of the components of the investment climate for value-added and export performance. The main reason could be that the dominant part of the added value of the automotive industry exports of these countries comes from the production phase (assembly), which is characterised by the lowest rate of its creation. If the absorption capacity of technology of the EU27 partner countries increased in terms of firm-level of technology absorption, this would harm all V4 countries in terms of added value creation. The only difference is in the magnitude of this negative impact. Based on the conclusions above, we also accept our second hypothesis. The hypothesis was supplemented with one more research question: What role does the firm level of technology absorption in EU27 countries (the most important trading partners of the V4 countries) play in creating added value in the V4 automotive sector? The high import requirements support the high export performance of the V4 countries. This finding is supported by the conclusions of some previous works (Puškárová, 2015), which point to the importance of imports for R\&D (innovation) outputs as an essential precondition for value-added growth. The most important trading partners are from the EU 27, and also the most extensive import requirements come from the EU trading partners. Firm-level technology absorption of $\mathrm{GCl}$ determines the quality of the business environment of the selected countries, leading to a certain level of competitiveness of the firms and countries. If the competitiveness of the EU trading partners in terms of the firmlevel technology absorption increases more than the competitiveness of the V4 countries, it reflects negatively in the lower relative level of the added value creation within the V4 countries. This affirmation can be supported by the fact that the most significant part of the added value creation in the automotive industry of V4 countries comes from the production phase, which is characterised with the lowest value-added creation according to the Smile curve (see Figure 3). The relationship between value-added and product completion phases within the automotive industry has been the subject of research by many studies and confirms our conclusion (Zábojník et al., 2020). Based on the above summary, we can prove that we answered the research question.

The research has some limitations, such as the extent of the time series from the TiVA database, which was limited in 2015. Based on this restricted time, we had to use data on the quality of the business environment in the form of 'Firm-level technology absorption' from 2012-2013 to ensure time lag between independent and dependent variables. Another limitation of the research is its geographical limitation to the most important trading partners of the V4 countries, other EU countries, as the vast majority of their production and exports have headed to this territory. Thus, we also limited the sample (number of observations) in the regression analysis to 27. 


\section{Conclusion}

The ability to create a certain level of value-added within a GVC varies considerably depending on its functions in the value chain. These individual functions are displayed by the smile curve, which we considered as a starting point for our research, in which we focused on the post-production phase. Either logistics or other supporting services represent this phase. Our research focused on transport and storage associated with product trade, and these services generate a greater volume of value-added in exports than the production phase itself.

The analysis of the 'smile curve' reveals that the V4 countries in the case of the automotive industry are mainly in the position of production and assembly. This further indicates a meager domestic rate of the value-added generated by this sector. We did not deal directly with low value-added levels within our regression models; instead we tried to find a possible explanation by using the indicator 'Firm-level technology absorption' from $\mathrm{GCl}$, which defines the level of quality in the business environment. Initially, it was expected that the value-added generated by that sector in the same company and country would increase upon implementing new progressive technologies in the automotive sector in a particular company and/or particular country. This statement could be true, provided that we exclude GVCs, which means that the production of one car depends on its components in many other countries and their subsequent export, re-export, import, and re-export, while being very dependent on logistics.

We have linked the degree of value-added of the automotive industry in each of the V4 countries to their competitiveness concerning their partner countries from the European Union, with which they carry out foreign trade exchanges. In this case, we can imagine foreign trade as export-import operations of components, which are the basis for the assembly of the final product (car). The partner countries make efforts (in our case, the remaining $26 \mathrm{EU}$ countries) to improve the business environment; we did not only take into account the quality of the business environment in the V4 country in our research while ignoring the quality of the business environment in other EU 26 partner countries. We also defined this business environment through the $\mathrm{GCl}$ indicator 'Firm-level technology absorption'. This enabled us to comprehensively analyse the relationship between the level of quality of the business environment both in the home country (each of the V4 countries) and in partner countries (26 remaining EU countries). We considered the 26 remaining EU countries as the most important trading partners of the V4 countries in relation to value creation in exports in the automotive sector of each of the V4 countries. The result may be surprising: if the quality of the business environment improves through the absorption of new technologies in all EU27 countries, there is a decrease in the value-added generated by the automotive sector in each of the V4 countries. The only difference lies within the extent to which this decline could cause. A possible explanation could be found in the 'smile curve'. Particularly the production phase is characterised by the lowest value-added within the automotive sector, thus lagging behind other phases with a higher rate of value-added, such as $R \& D$, design, marketing, logistics, etc. It follows that the growth of value-added caused by the growth of the quality of the business environment through firm-level technology absorption in each of the V4 countries (production phase on the smile curve) cannot keep pace with the growth of valueadded caused by the growth of the quality of the penetrating environment through firm-level technology absorption in the remaining $26 \mathrm{EU}$ countries. We believe that this situation will 
persist unless there is a shift in the V4 countries of interest within the automotive to phases focused on R\&D, design, marketing, logistics, such that the phases that we have identified above as those in which a higher rate is generated.

The article further evaluated the foreign value-added generated by the transport and storage sectors in the exports of motor vehicles, trailers, and semi-trailers, while the EU27 countries were considered a foreign source of value-added. In the case of the V4 countries, the results of the regression analysis confirmed that there is an interaction among these countries. In other words, there is not only a positive impact of the import of transport services from the EU26 countries to individual V4 countries on its value-added creation in gross exports, but there is also an evident positive or negative impact of the import of these services to the rest of the V4 countries on any particular V4 country to a certain extent. It means the import of such services to country $X$ (e.g. SK), to country $Y$ (e.g. CZ), to country $Z$ (e.g. HU) all have an impact on the value-added creation of the export of the automotive sector of the country $\mathrm{T}$ (e.g. PL). A concrete example proves the interaction of CZ and SK (models $A$ and $B$ ), or the interaction of PL, CZ, SK, and $\mathrm{HU}$ (model C). In the case of HU, we found a negative effect on the amount of value-added generated in PL. We identified that an explanation could be sought, e.g. in the existence of clusters and their importance for the automotive industry in these V4 countries. The automotive industry, in general, is organised in clusters, which in the case of SK, CZ and PL can also be confirmed by the geographical location of many manufacturing plants and their subcontractors. In this sense, $\mathrm{HU}$ is geographically apart but still within the V4 countries. For this reason, we assume that clustering in relation to $\mathrm{SK}, \mathrm{CZ}$, and $\mathrm{PL}$ is more intense than the clustering of these three countries together with $\mathrm{HU}$. This may also result in a negative impact of the import of transport services to $\mathrm{HU}$ on value-added creation in PL export of motor vehicles, trailers, and semi-trailers (model C) or no impact of transport services to HU on value-added creation in SK export of the motor vehicles, trailers, and semi-trailers (model A).

Based on the findings above, we accept our hypothesis $\mathrm{H} 1$ with the formulation: The amount of value-added originated in transport and storage in exports of the automotive industry of each V4 country depends on the total import of transport services from the EU27 countries. This hypothesis was supplemented with the research question of whether there is a synergic or spillover effect within the automotive clusters of the V4 countries in creating value-added originating in the logistic services. This question is also answered, as these effects have been confirmed among the V4 countries.

Further research, based on the usage of more granular data or panel data, could provide more insights into determinants of GVCs participation from a policy-making perspective. This research will try to contrast the results of current research with the importance of implementing and absorbing new technologies by the corporate sector, which determines the quality of the business environment concerning the value-added from the logistics services sector in the automotive export countries such as Germany, France, or United Kingdom. We consider these countries to be the host of several parent companies operating in the automotive industry of the V4 countries. The expected results should reveal their positioning within the smile curve in the phases of R\&D, design, marketing, logistics, etc., in contrast to the production phase, which dominates in the V4 countries. 


\section{Acknowledgement}

This paper is an output of research projects of the Ministry of Education, Science, Research and Sport of the Slovak Republic: VEGA (in the period 2020-2022) No. 1/0777/20: Belt and Road initiative - Opportunity or threat for the EU and Slovak export competitiveness?; VEGA (in the period 2020-2022) No. 1/0039/20: The importance of the Eurasian Economic Union for Shaping of EU Trade Strategies (with Implications for Slovakia); VEGA (in the period 2019-2021) No. 1/0420/19: The importance of trade cooperation between the EU and the countries of the Western Balkans in terms of the possibilities of expansion of business entities; and the research project of the Visegrad Fund (in the period 2021-2022) No. 22030183: GVCs in Central Europe - a perspective of automotive sector after COVID-19.

\section{References}

Bair, J. (2005). Global capitalism and commodity chains: Looking back, going forward. Competition \& Change, 9(2), 153-180. https://doi.org/10.1179/102452905X45382

Baldwin, R., Forslid, R., \& Ito, T. (2015). Unveiling the evolving sources of value added in exports. IDEJETRO, Joint Research Program Series, No. 161. https://www.ide.go.jp/library/English/Publish/Reports/Jrp/pdf/161.pdf.

Biesebroeck, J., \& Sturgeon, T. (2011). Global value chains in the automotive industry: An enhanced role for developing countries? International Journal of Technological Learning, Innovation and Development, 4(1/2/3), 181-205. https://doi.org/10.1504/IJTLID.2011.041904

Börjesson, M., \& Eliasson, J. (2019). Should values of time be differentiated? Transport Reviews, 39(3), 357-375. https://doi.org/10.1080/01441647.2018.1480543

Calabrese, G.G. (2018). Global value chain in the automotive industry: Challenges and new trends. $E A D$ 5977 - New trends in products, processes, technologies and transitions in automotive industry. IRCrES, USP. https://edisciplinas.usp.br/pluginfile.php/4325260/mod_folder/content/0/Calabrese\%20$\% 20$ Automotive\%20GVC.pdf.

Cattaneo, O., Gereffi, G., \& Staritz, C. (2010). Global value chains in a postcrisis world: A development perspective. Worldbank.org. https://openknowledge.worldbank.org/handle/10986/2509.

Dębkowska, K. et al. (2019). The automotive industry in the Visegrad Group countries. Polish Economic Institute. https://pie.net.pl/wp-content/uploads/2019/08/PIE-Raport_Automotive.pdf.

Dollar, D., Khan, B., \& Pei, J. (2019). Should high domestic value added in exports be an objective of policy? In WTO, Global Value Chain Development Report 2019: Technological Innovation, Supply Chain Trade, and Workers in a Globalised World, (141-153). https://www.wto.org/english/res_e/booksp_e/gvc_dev_report_2019_e_ch7.pdf.

Faezeh, R., Ignatenko, A., \& Mircheva, B. (2019). Global value chains: What are the benefits and why do countries participate? International Monetary Fund [Working paper no. 19/18]. https://www.imf.org/en/Publications/WP/Issues/2019/01/18/Global-Value-Chains-What-are-theBenefits-and-Why-Do-Countries-Participate-46505.

Fernandez-Stark, K., Bamber, P., \& Gereffi, G. (2014). Global value chains in Latin America: A development perspective for upgrading. In R. A. Hermández, J. M. Martinéz-Piva \& N. Mulder (Eds.), Global value chains and world trade: Prospects and challenges for Latin America, (79106). ECLAC. 
Folfas, P. (2017). Poland in international production networks of automotive industry. Annuals of the Administration and Law, 17(2), 161-172. https://www.humanitas.edu.pl/resources/upload/dokumenty/Wydawnictwo/Roczniki\%20AiP\%2 0-\%20pliki/Podzielone/Roczniki\%20AiP\%202017\%20z2/RAiP_2_2017-161-172.pdf

Folfas, P., \& Udvari, B. (2019). Chemical industry and value-added trade - A comparative study on Hungary and Poland. Acta Oeconomica, 69(1), 81-99. https://doi.org/10.1556/032.2019.69.1.5

Gereffi, G. (1994). The organisation of buyer-driven global commodity chains: How US retailers shape overseas production networks. In G. Gereffi \& M. Korzeniewicz (Eds.), Commodity chains and global capitalism, (95-122). Praeger.

Gerocs, T., \& Pinkasz, A. (2019). Relocation, standardisation and vertical specialisation: ore-periphery relations in the European automotive value chain. Society and Economy, 41(2), 171-192. https://doi.org/10.1556/204.2019.001

Goldberg, P. K., Amit Khandelwal, A., Pavcnik, N., \& Topalova, P. (2010). Imported intermediate inputs and domestic product growth: Evidence from India. The Quarterly Journal of Economics, 125(4), 1727-1767. https://doi.org/10.1162/qjec.2010.125.4.1727

Grossman, G. M., \& Rossi-Hansberg, E. (2008). Trading tasks: A simple theory of offshoring. American Economic Review, 98(5), 1978-1997. https://doi.org/ 10.1257/aer.98.5.1978

Hudson, R. (2004). Conceptualising economies and their geographies: Spaces, flows and circuits. Progress in Human Geography, 28(4), 447-471. https://doi.org/10.1191/0309132504ph497oa

Humphrey, J., \& Schmitz, H. (2002). How does insertion in global value chains affect upgrading industrial clusters? Regional Studies, 36(9), 1017-1027. https://doi.org/10.1080/0034340022000022198

Koopman, R., Wang, Z., \& Wei, S. J. (2014). Tracing value-added and double counting in gross exports. American Economic Review, 104(2), 459-494. https://doi.org/10,1257 / aer.104.2.459

Kowalski, P., Gonzalez, J. L., Ragoussis, A., \& Ugarte, C. (2015). Participation of developing countries in global value chains. OECD Trade Policy Papers, No.179. https://doi.org/10.1787/5js33lfw0xxn-en

Krugman, P. et al. (1991). Geography and trade. MIT Press.

Lamy, P. (2012, April 17). Trade improves the lives of people. Wto.org. https://www.wto.org/english/news_e/sppl_e/sppl224_e.htm

Lorentzen, J., Muller, L., Manamela, A., \& Gastrow, M. (2011). Smart specialisation and global competitiveness: Multinational enterprises and location-specific assets in Cape Town. African Journal of Business Management, 5(12), 4782-4791.

Luptáčik, M., Habrman, M., Lábaj, M., \& Rehák, Š. (2013). The importance of automotive industry for the Slovak economy: Empirical results [Final report]. University of Economics in Bratislava. https://www.zapsr.sk/wp-content/uploads/2013/12/Final-Report-Automotive-Industry.pdf

OECD. (2013). Interconnected Economies: Benefiting From Global Value Chains. OECD, 29-30 May 2013. https://www.oecd.org/mcm/C-MIN(2013)15-ENG.pdf

OECD. (2015). Trade in Value Added (TiVA): October 2015: Trade in Value Added (TiVA): Core Indicators. OECD.Stat. https://stats.oecd.org/Index.aspx?Queryld=66268

OECD. (2019). Guide to OECD's trade in value added (TiVA) indicators, 2018 edition. OECD, Directorate for Science, Technology and Innovation. https://www.oecd.org/sti/ind/tiva/TiVA2018_Indicators_Guide.pdf

OECD. (2021). OECD.Stat. https://stats.oecd.org/\#. 
Pavlínek, P. (2018). Global production networks, foreign direct investment, and supplier linkages in the integrated peripheries of the automotive industry. Economic Geography, 94(2), 141-165. https://doi.org/10.1080/00130095.2017.1393313

Porter, M. E. (1985). The competitive advantage: creating and sustaining superior performance. Free Press.

Puskarova, P. (2015). Assessing the magnitude of globalisation-induced technology flows in expanded EU-sample: a multi-channel approach. Procedia Economics and Finance, 20, 544-552. https://doi.org/10.1016/S2212-5671(15)00107-0

Ruzekova, V., Kittova, Z., \& Steinhauser, D. (2020). Export Performance as a Measurement of Competitiveness. Journal of Competitiveness, 12(1), 145-160. https://doi.org/10.7441/joc.2020.01.09

Shih, S. (1992). Empowering technology-making your life easier. Acer's Report, Acer's, New Taipei.

Timmer, M. P., Erumban, A. A., Los, B., Stehrer, R., \& de Vries, G. J. (2014). Slicing up global value chains. Journal of Economic Perspectives, 28(2), 99-118. https://doi.org/10.1257/jep.28.2.99

WEF. (2012). The Global Competitiveness Report 2012-20013. http://www3.weforum.org/docs/WEF_GlobalCompetitivenessReport_2012-13.pdf.

Zábojník, S., Čiderová, D., \& Krajčík, D. (2020). Competitiveness in international business. Wolters Kluwer.

The research article passed the review process. | Received: July 5, 2021; Revised: October 27, 2021; Accepted: December 10, 2021; Pre-published online: March 7, 2022; Published in the regular issue: September 19, 2022. 